ORIGINAL

\title{
Protozoan and metazoan parasites of Nile tilapia Oreochromis niloticus cultured in Brazil
}

\section{Parásitos protozoarios y metazoarios de la tilapia del Nilo Oreochromis niloticus criadas en Brasil}

\author{
Wanderson Pantoja MF, ${ }^{1}$ Fishing Engineer, Ligia Neves $\mathrm{R}^{1}$ Fishing Engineer, \\ Márcia Dias RD, 1,2 Biologist, Renata Marinho GB, 1,2 Zoo Technician, \\ Daniel Montagner, ${ }^{1}$ M.Sc, Marcos Tavares-Dias, ${ }^{1 *}$ Ph.D.
}

\begin{abstract}
${ }^{1}$ Embrapa Amapá, Laboratório de Aquicultura e Pesca, Macapá, AP, Brasil. 2Universidade Federal do Amapá (UNIFAP), Programa de Pós-Graduação em Biodiversidade Tropical, Macapá, AP, Brasil. Correspondence: marcostavares@cpafap.embrapa.br
\end{abstract}

Recibido: Marzo de 2011; Aceptado Diciembre de 2011.

\begin{abstract}
Objective. This study describes the parasitic fauna and relative condition factor $(\mathrm{Kn})$ in Nile tilapia Oreochromis niloticus L. (Cichlidae) from fish farms in the State of Amapá. Material and methods. 123 fish from four fish farms in the state of Amapá, Brazil were necropsied for parasitological and Kn analysis. Results. $64.2 \%$ of the examined fish, had the gills infected with Cichlidogyrus tilapiae Paperna, 1960 (Monogenoidea: Dactylogyridae); Ichthyophthirius multifiliis Fouquet, 1876 (Protozoa: Ciliophora), Trichodina Ehrenberg, 1830 and Paratrichodina africana Kazubski \& El-Tantawy, 1986 (Protozoa: Trichodinidae). The highest prevalence found corresponded to Monogenoidea C. tilapiae while the lowest corresponded to Trichodinidae. However, I. multifiliis was the parasite that presented the greatest intensity and abundance. The differences found in the infection rates of the different fish farms due to causes further discussed. The parasitism did not influence the relative condition factor $(\mathrm{Kn})$ of fish. This was the first record of $P$. africana in Brazil and occurred in the Eastern Amazon. Conclusions. In Brazil, Lamproglena sp. is an emerging parasite in the Southern and Southeastern regions, but this crustacean was not found in the Nile tilapia in the State of Amapá. The parasitic infections in Nile tilapia farmed in Brazil are caused by protozoan, monogenoidea, crustacea and digenea species, and the regional differences on their prevalence and intensity rates are discussed in this study.
\end{abstract}

Key words: Freshwater fishes, parasites, prevalence, Oreochromis niloticus (Source: CAB). 


\section{RESUMEM}

Objetivo. Describir la parasitofauna y el factor de condición relativa $(\mathrm{Kn})$ de la tilapia del Nilo Oreochromis niloticus L. (Cichlidae) en granjas piscícolas del estado de Amapá. Materiales y métodos. 123 peces, de cuatro granjas piscícolas del Estado del Amapá, Brasil, fueron necropciados para realizarles un análisis parasitólogico y el análisis Kn. Resultados. De los peces examinados, $64.2 \%$ estaban con las branquias infectadas por Cichlidogyrus tilapiae Paperna, 1960 (Monogenoidea: Dactylogyridae), Ichthyophthirius multifiliis Fouquet, 1876 (Protozoa: Ciliophora), Trichodina Ehrenberg, 1830 y Paratrichodina africana Kazubski \& El-Tantawy, 1986 (Protozoa: Trichodinidae). La mayor prevalencia fue de Monogenoidea $C$. tilapiae, mientras que la menor fue de los parásitos Trichodinidae. Sin embargo, I. multifiliis fue el parásito que mostró la mayor intensidad y abundancia. Las diferencias encontradas estuvieron en las tasas de infección parasitaria de diferentes granjas piscícolas debido a las causas aquí discutidas. El parasitismo no influenció el factor de condición relativa (Kn). Este fue el primer registro de P. africana para el Brasil, en la Amazonía Oriental. Conclusiones. En el Brasil, Lamproglena sp es un parásito emergente en las regiones del Sur y Suroeste, pero este crustáceo no fue encontrado en la tilapia del Nilo del Estado de Amapá. En la tilapia del Nilo criada en el Brasil, las infecciones parasitarías son causadas por especies de protozoarios, monogenoideas, crustáceos y digenéticos; las diferencias regionales en las tasa de prevalencia e intensidad son discutidas aquí.

Palabras clave: Parásitos, peces de agua dulce, prevalencia, Oreochromis niloticus (Fuente:CAB).

\section{INTRODUCTION}

The freshwater aquaculture in Brazil has been growing, driven especially by fish farming, which represents the bulk of the domestic production. The Nile tilapia Oreochromis niloticus is the species making the greatest contribution to the growth of this production, representing $39 \%$ of all fish from freshwater fish farming (1). Culture of this fish occurs mainly in the Northeastern, Southern, Midwestern and Southeastern areas, but the largest production is found in the Northeast (1). This production at high stocking densities is done mainly in tanks, besides ponds.

In northern Brazil, the production of Nile tilapia is small, since it is cultured only in the States of Rondônia, Acre, Pará and Amapá. In the state of Amapá, the Nile tilapia was introduced in the early 90's by the former Aquiap (Aquaculturers of Amapá Association). The choice for the cultivation of this non-native fish in the state of Amapá was due to its rapid reproduction rate which allows the quick replenishment of the tanks of the pirarucu Arapaima gigas. Thus, the production of the Nile tilapia grew from 2004 to 2007, going from 10 to 30 tons (1).

The fish live in balance with the parasites, but this balance can be broken, mainly by environmental disturbances, among which the changes in the water quality have a relevant role $(2,3)$, as well as inadequate management and high stocking densities of fish $(3,4)$. Therefore, in systems of intensive culture, problems of infections caused by protozoan and metazoan are quite frequent. Protozoan parasites are common in farmed fish and can cause economic losses in fish farms. Metazoan are parasites that can cause gill infections, damage to eyes and internal organs, starvation, inflammation of the swim bladder, and inhibited oxygen exchange across gill lamella. They provide portals of entry for bacteria in fish. Therefore, these parasites can be limiting factors for the development of fish farm as they cause low growth of fish and diseases, reducing profitability and increasing the costs of production due to treatments. Thus, epidemiological studies in fish farms are important for adapting the management techniques and providing sanitary guidelines.

In Brazil, the parasitic fauna in Nile tilapia has been studied primarily in fish farms in the states of São Paulo, Santa Catarina and Paraná, but the information are scattered in the literature. In addition, there is no information about the parasitic fauna in this cichlid cultured in the North, so some important issues remain open. Thus, the objectives of this study were to determine the prevalence rate and mean intensity of protozoan and metazoan parasites, as well as the condition factor in O. niloticus cultured in the State of Amapá (Northern region).

\section{MATERIAL AND METHODS}

Study site. Specimens of Nile tilapia were collected from August 2009 to March 2010 in four fish farms in the city of Macapá, state of Amapá (Brazil) for parasitological analysis. 
Conservation fishes. In ponds of different sizes, the fish were maintained with an artificial diet and ignored stocking density, since they were not sexually reversed.

Parasitological analysis. All fish were collected with net, weighed $(\mathrm{g})$ and measured $(\mathrm{cm})$. Then, they were necropsied for parasitological analysis. Each specimen had its mouth, opercula, gills and gastrointestinal tract examined. The methodology used for collection, fixation and quantification of parasites followed previous recommendations $(5,6)$. Identification of parasites was done in accordance to suggestions from the literature (7-9). The ecological terms were according to Bush et al (10) and Rhode et al (11).

Data analysis. With the weight and total length data, the relative condition factor $(\mathrm{Kn})$ of the parasitized and non-parasitized fish was determined. The differences between parasitized and non-parasitized fish were compared through the test $t \quad(p<0.05)$. Spearman's rank ( $r s$ ) correlation coefficient was used to determine possible correlations between the total length and weight of the hosts and the number of parasites. At each fish collection, the potential for hydrogen $(\mathrm{pH})$, the temperature and dissolved oxygen concentration (DO) of the nurseries were measured with digital (YSI) equipments, respectively.

\section{RESULTS}

The temperature and the $\mathrm{pH}$ of ponds water were similar; however, the dissolved oxygen levels were lower in the fish farm 2 and 3 (Figure 1).

A total of 123 Nile tilapia were examined in four fish farms in Macapá (State of Amapá) and weigh and total length mean \pm standard deviation are described on Table 1. In the four fish farms, $64.2 \%$ of fish were parasitized by one or more parasites (Table 1), such as: Ichthyophthirius multifiliis Fouquet, 1876 (Protozoa), Paratrichodina africana Kazubski \& El-Tantawy, 1986 (Protozoa: Trichodinidae), Trichodina
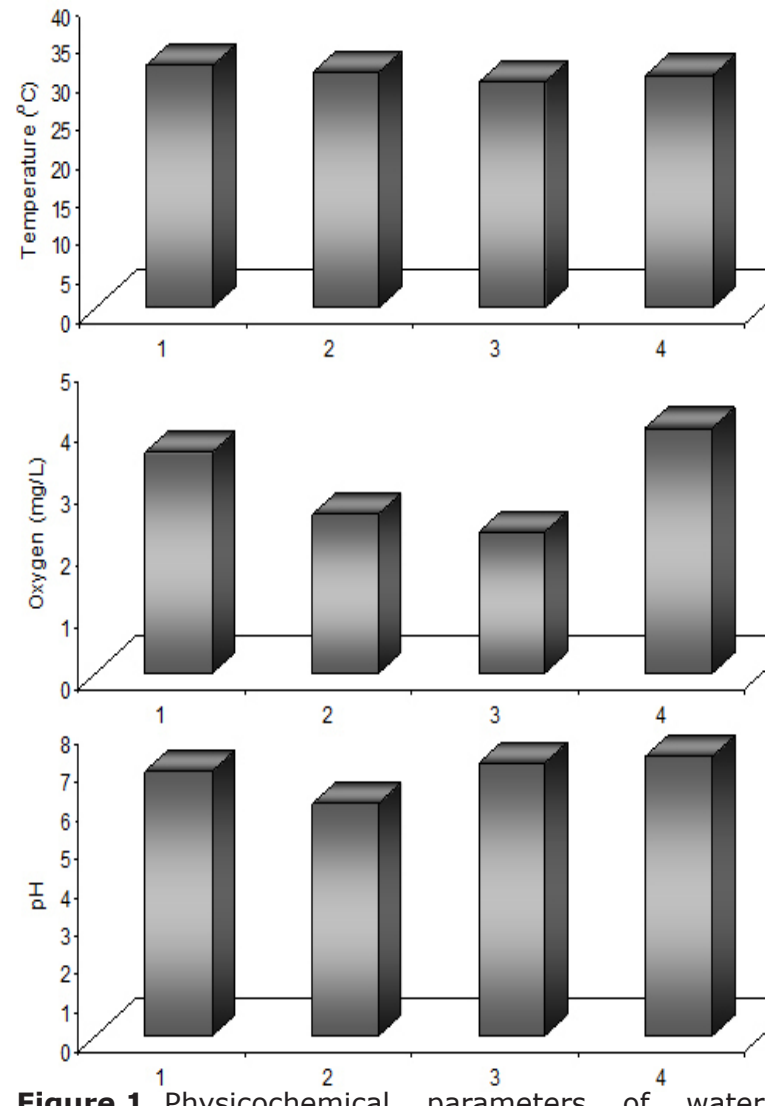

Figure 1. Physicochemical parameters of water quality in ponds from four fish farms in the State of Amapá.

Ehrenberg, 1830 (Protozoa: Trichodinidae) and Cichlidogyrus tilapiae Paperna, 1960 (Monogenoidea: Dactylogyridae). The highest prevalence of parasitic infection was observed in the fish farm 2 and the lowest prevalence in the fish farm 4. In the other fish farms (1 and 3 ) there was not a significant difference in the prevalence, which was of $73.6 \%$ and $76.0 \%$ respectively (Table 1 ).

Infections by $I$. multifiliis were observed in Nile tilapia cultured in three of the four fish farms investigated. However, the lowest rates of parasitism occurred in the fish farm 1 and the highest in the fish farm 3 . The rates of infection by Trichodinidae were similar in the three fish

Table 1. Mean values \pm standard deviation of weigh and total length of Nile tilapia collected in four fish farms from the state of Amapá. EF: examined fish; PF: parasitized fish, P: Prevalence.

\begin{tabular}{ccccccc}
\hline Fish farms & Geographic coordinates & Weight $(\mathbf{g})$ & Length $(\mathbf{c m})$ & EF & PF & P (\%) \\
\hline 1 & $0^{\circ} 02^{\prime} 31.4^{\prime \prime} \mathrm{S}, 051^{\circ} 07^{\prime} 34.4^{\prime \prime} \mathrm{W}$ & $44.0 \pm 31.7$ & $12.6 \pm 2.7$ & 38 & 28 & 73.6 \\
2 & $0^{\circ} 00^{\prime} 58.1^{\prime \prime} \mathrm{S}, 051^{\circ} 06^{\prime} 31.8^{\prime \prime} \mathrm{W}$ & $51.1 \pm 44.9$ & $12.9 \pm 3.7$ & 32 & 29 & 90.6 \\
3 & $0^{\circ} 00^{\prime} 36.8^{\prime \prime} \mathrm{S}, 051^{\circ} 06^{\prime} 13.7^{\prime \prime} \mathrm{W}$ & $135.8 \pm 36.7$ & $19.1 \pm 2.0$ & 25 & 19 & 76.0 \\
4 & $0^{\circ} 00^{\prime} 04.5^{\prime \prime} \mathrm{N}, 051^{\circ} 05^{\prime} 52.1^{\prime \prime} \mathrm{W}$ & $55.2 \pm 68.8$ & $12.6 \pm 4.2$ & 28 & 3 & 10.7 \\
\hline Total & - & - & - & $\mathbf{1 2 3}$ & $\mathbf{7 9}$
\end{tabular}


Table 2. Parasitological indices of Ichthyophthirius multifiliis and Trichodinidae on the gills of Nile tilapia from four fish farms from the state of Amapá.

\begin{tabular}{lcccccccc}
\hline Parasites & \multicolumn{3}{c}{ Ichthyophthirius multifiliis } & \multicolumn{3}{c}{ Trichodinidae } \\
Fish farms & 1 & 2 & 3 & 4 & 1 & 2 & 3 & 4 \\
\hline EF & 38 & 32 & 25 & 28 & 38 & 32 & 25 & 28 \\
PF & 13 & 17 & 19 & 0 & 3 & 1 & 1 & 0 \\
P (\%) & 34.2 & 53.1 & 76.0 & 0 & 7.9 & 3.1 & 4.0 & 0 \\
MI & 700.8 & 7183.9 & $75.198,4$ & 0 & 1957.3 & 6800 & 9894 & 0 \\
MA & 239.7 & 3816.5 & $57.150,8$ & 0 & 1545 & 206.1 & 395.7 & 0 \\
Range & $120-$ & $4.100-$ & $13.108-$ & 0 & $735-$ & - & - & 0 \\
TNP & 2550 & 14.800 & 282.785 & 0 & 3180 & & & \\
\hline
\end{tabular}

EF: examined fish; PF:parasitized fish; P:Prevalence; MI:Mean intensity of infection; MA:Mean abundance; TNP:Total number of parasites.

farms in which there was parasitism (Table 2) and two species were identified. $P$. Africana was found in the fish farm 1 and Trichodina sp. was found in the fish farms 2 and 3.

In tilapia from the fish farms 3 and 4, infection rates for $C$. tilapiae were lower than the ones from the fish farms 1 and 2 (Table 3 ).

Table 3. Parasitological indices of Cichlidogyrus tilapiae on the gills of Nile tilapia from four fish farms in the state of Amapá.

\begin{tabular}{lcccc}
\hline Fish farms & $\mathbf{1}$ & $\mathbf{2}$ & $\mathbf{3}$ & $\mathbf{4}$ \\
\hline EF & 38 & 32 & 25 & 28 \\
PF & 28 & 22 & 2 & 3 \\
P (\%) & 73.7 & 68.7 & 8.0 & 10.7 \\
MI & 12.3 & 7.6 & 3.5 & 11.0 \\
MA & 9.0 & 5.2 & 0.28 & 1.2 \\
Range & $2-51$ & $3-17$ & $1-6$ & $4-23$ \\
TNP & 343 & 168 & 7 & 33
\end{tabular}

EF:examined fish; PF:parasitized fish; P:Prevalence; MI:Mean intensity of infection; MA:Mean abundance; TNP:Total number of parasites.

The Protozoan I. multifiliis was the parasite with the greatest abundance and relative dominance (Table 4) and it showed a positive correlation with the weigh and length of 0 . niloticus (Figure 2).

Table 4. Total parasitological indices in Nile tilapia in the state of Amapá.

\begin{tabular}{lccc}
\hline Parasites & C. tilapiae & I. multifiliis & Trichodinidae \\
\hline EF & 123 & 123 & 123 \\
PF & 55 & 49 & 5 \\
P (\%) & 44.7 & 39.8 & 4.1 \\
MI & 10.0 & $31.836,9$ & 4513.2 \\
MA & 4.5 & 12.683 & 183.5 \\
TNP & 551 & $1.560,007$ & 22.566 \\
MRD & 0.0003 & 0.9854 & 0.01425
\end{tabular}

EF: examined fish; PF: parasitized fish; P: Prevalence; MI: Mean intensity of infection; MA: Mean abundance; TNP: Total number of parasites; MRD: Mean relative dominance.

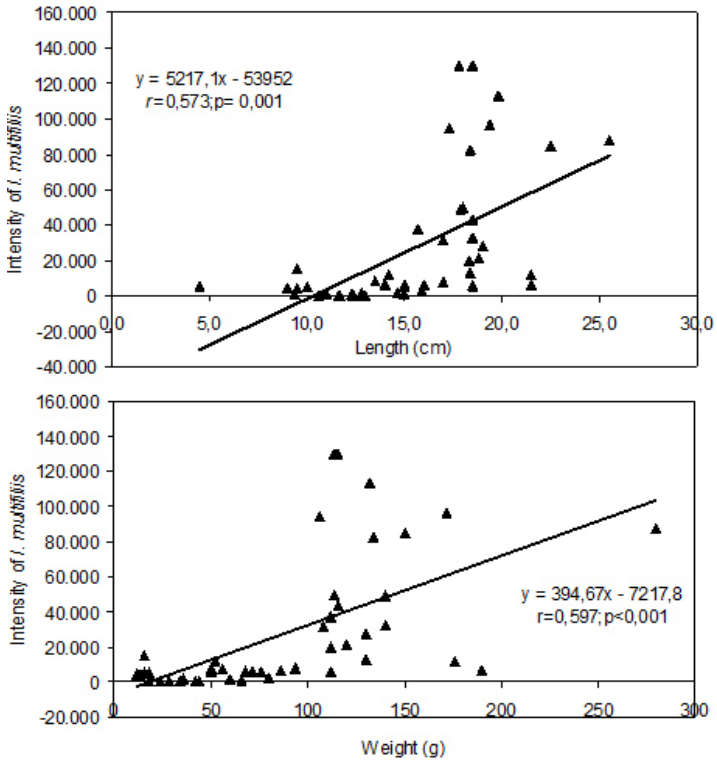

Figure 2. Intensity ratio of Ichthyophthirius multifiliis with the total length and weigh in Nile tilapia $(\mathrm{N}=48)$ cultured in the state of Amapá.

On the other hand, Trichodinidae $P$. africana and Trichodina sp. were the less prevalent parasites and showed a higher relative dominance when compared to C. tilapiae (Table 4).

$\mathrm{Kn}$ of parasitized $(0.999 \pm 0.012)$ and nonparasitized $(1.00 \pm 0.03) 0$. niloticus showed no significant difference $(p=0.676)$.

\section{DISCUSSION}

In Brazil, Trichodinidae are the most common protozoan affecting cultivated Nile tilapia, especially in the South where their culture has been intensified (Table 5). However, few species are described in Brazil, since in general, they are described as Trichodina sp (3,5,12-23). These parasites are important agents causing diseases in Nile tilapia and most Trichodinidae species do not show host specificity (24). In Nile tilapia grown in Bangladesh, Trichodinidae were the most frequent parasites, with a prevalence ranging from 24.2-90.2\%, depending on the fish farm and the time of the year. In addition, the high prevalence proved to be correlated with the high stocking density of fish and with the physicochemical parameters of the water (2). Therefore, these results indicate the aggregate pattern of distribution of the Trichodinidae, causing these high prevalence rates when fish are kept in high stocking densities during culture. 
Table 5. Parasites of Nile tilapia cultured in different Brazilian states.

\begin{tabular}{|c|c|c|c|c|}
\hline Group/Species & Culture/State & Prevalence (\%) & Mean Intensity & References \\
\hline \multicolumn{5}{|l|}{ PROTOZOA } \\
\hline I. multifilis & Feefishing (SP) & 4.0 & 76.0 & 5 \\
\hline I. multifilis & Net cage (SP) & 3.2 & - & 14 \\
\hline I. multifilis & Fish farm and Feefishing (PR) & $21.3-25.0$ & - & 15 \\
\hline I. multifilis & Feefishing (PR) & $1.8-2.5$ & - & 12 \\
\hline I. multifilis & Fish farm (PR) & 26.0 & - & 16 \\
\hline Trichodina sp. & Feefishing (PR) & $15.8-18.3$ & - & 12 \\
\hline Trichodina sp. & Fish farm (PR) & 43.0 & - & 16 \\
\hline Trichodina sp. & Fish farm (PR) & $62.5-72.5$ & - & 15 \\
\hline Trichodina sp. & Fish farm (PR) & $17.0-72.0$ & - & 17 \\
\hline Trichodina sp. & Net cage (PR) & $13.3-50.0$ & - & 18 \\
\hline Trichodinidae & Net cage (PR) & $13.9-17.4$ & - & 19 \\
\hline Trichodina $s p$. & Net cage (SP) & $24.0-38.1$ & - & 14 \\
\hline Trichodina sp. & Fish farm (SP) & 8.0 & 243 & 5 \\
\hline Trichodina $s p$. & Feefishing (SC) & 1.6 & - & 20 \\
\hline Trichodina magna & Fish farm (SC) & 24.7 & - & 22 \\
\hline Trichodina compacta & Fish farm (SC) & 24.7 & - & 23 \\
\hline T. compacta and T. magna & Fish farm (SC) & $10.0-51.0$ & $55.1-621.9$ & 21 \\
\hline T. compacta and T. magna & Fish farm (SC) & 81.0 & - & 13 \\
\hline T. compacta and T. magna & Fish farm and Feefishing (SC) & $0.6-1.7$ & - & 3 \\
\hline \multicolumn{5}{|l|}{ MONOGENOIDEA } \\
\hline Cichlidogyrus sp. & Fish farm (RJ) & 12.8 & 1.1 & 25 \\
\hline Dactylogyrus sp. & Net cage (SP) & $52.8-83.3$ & $65.6-112.8$ & 26 \\
\hline $\begin{array}{l}\text { Cichlidogyrus sclerosus and } \\
\text { Cichlidogyrus sp. }\end{array}$ & Fish farm (SP) & $6.7-43.8$ & $3.6-7.3$ & 4 \\
\hline Dactylogyridae & Fish farm (PR) & $3.3-10.0$ & - & 18 \\
\hline Dactylogyridae & Feefishing (PR) & $25.8-53.3$ & - & 12 \\
\hline Dactylogyrus sp. & Fish farm (PR) & 49.0 & 0.8 & 16 \\
\hline Gyrodactylogyridae & Feefishing (PR) & 0.8 & - & 12 \\
\hline Cichlidogyrus sp. and C. sclerosus & Feefishing (SC) & 13.3 & 4.2 & 20 \\
\hline $\begin{array}{l}\text { Cichlidogyrus sp., C. sclerosus and } \\
\text { Gyrodactylus sp. }\end{array}$ & Fish farm (SC) & $28.0-83$ & $1.3-34.5$ & 21 \\
\hline $\begin{array}{l}\text { Cichlidogyrus sp., C. sclerosus } \\
\text { and Gyrodactylus }\end{array}$ & Fish farm (SC) & 76.0 & - & 13 \\
\hline Cichlidogyrus sp. and C. sclerosus & Feefishing (SC) & $13.2-16.5$ & $0.8-2.6$ & 3 \\
\hline \multicolumn{5}{|l|}{ DIGENEA } \\
\hline Clinostomum complamatum & Fish farm (RS) & 100 & - & 27 \\
\hline Diplostomum sp. & Net cage (SP) & 4.8 & - & 14 \\
\hline \multicolumn{5}{|l|}{ CRUSTACEA } \\
\hline Ergasilidae & Fish farm (SP) & 18.0 & 3.4 & 6 \\
\hline Ergasilus sp. & Fish farm (RJ) & 18.2 & 2.0 & 25 \\
\hline Lamproglena sp. & Fish farm (RJ) & 60.0 & 3.4 & 25 \\
\hline Lamproglena sp. & Fish farm (SP) & 67.4 & 5.2 & 4 \\
\hline Lamproglena sp. & Feefishing (SC) & 3.3 & 1.5 & 20 \\
\hline Lamproglena sp. & Fish farm (SC) & $3.0-22.0$ & $0.3-0.8$ & 21 \\
\hline Lamproglena sp. & Fish farm (SC) & 9.0 & - & 13 \\
\hline Lamproglena sp. & Fish farm (SC) & $0.5-1.7$ & $0.1-0.2$ & 3 \\
\hline Argulus spinulosus & Fish farm (SC) & 33.0 & 1.7 & 21 \\
\hline Dolops carvalhoi & Net cage (SP) & 1.6 & - & 14 \\
\hline
\end{tabular}


Several species of Trichodinidae are distributed worldwide due to the transcontinental introduction of fish (24). Martins \& Ghiraldelli (22) mention that the Trichodina, Trichodinella and Paratrichodina have been described parasitizing tilapia. Trichodina compacta is common in the skin and gills of several families of freshwater fish from Africa, Taiwan and Philippines, but it has a clear preference for Cichlid species (24). Paratrichodina africana occurs in $100 \%$ of tilapia from Lake Vitoria in Kenya and in $64.7 \%$ of tilapia from the Nile Delta in Egypt $(8,9)$. In tilapia $O$. niloticus from three fish farms in the state of Amapá, rates of infection by Trichodina sp. and $P$. Africana were similar. However, the prevalence was lower than that reported for the same host grown in other regions of Brazil, while the intensity was higher (Table 5). Trichodinidae reproduction is favored by the excess of organic matter in the culture ponds $(3,21,22)$ and by the high temperatures $(2,3)$ such as the ones that occur in the region of this study.

Ichthyophthirius multifiliis is one of the biggest responsible for significant economic losses in fish farms worldwide (28). In Nile tilapia reared in several localities in Brazil, it is the second protozoan causing infections (Table 5), which proves its great adaption also in tropical areas. In the gills of $O$. niloticus cultivated in the State of Amapá, the intensity of $I$. multifiliis was positively correlated with weigh and length, which indicates an increase of parasitism according to the growth of fish. An increase in the number of parasites is due to cumulative process since the gills increase their surface area in proportion to an increase in fish growth (25). There is a proportional increase in habitat for reproduction of this protozoan.

The ichthyophthiriasis often manifests itself after handling operations during cold seasons and in other stressful situations (5). High rates of infections by $I$. multifiliis were found in tilapia from three fish farms in the state of Amapá, in the eastern Amazon, where temperatures are higher and more constant than in other Brazilian regions. However differences in the abundance and prevalence for the same host in different regions may be due to the balance between the host immune system and the performance of the parasite.

Monogenoidea is the main metazoan parasite infecting cultured tilapia in Brazil, mainly Cichlidogyrus Paperna, 1960 (Table 5). However there are few records of mortality caused by severe infections in cichlid fish. These parasites have been responsible for $80.0 \%$ of the infections in Nile tilapia grown in the state of Santa Catarina; $40.0 \%$ in the ones grown in the state of São Paulo and $16.0 \%$ in the ones grown in the state of Paraná (29).
Parasitism by C. tilapiae was high only in tilapia from two of the investigated fish farms. However the indices were similar to the ones described for this same host grown in the southern Brazil (Table 5). Banu \& Khan (2) have demonstrated that in tilapia grown in Bangladesh, Monogenoidea was the second most frequent parasite throughout the year and that their prevalence was correlated with the physicochemical parameters of the water. In a polluted environment, there is a decrease in the abundance of Cichlidogyrus sclerosus, as well as in the immunological resistance of tilapia, thereby increasing the persistence of this infection. Therefore, in tropical environments, this parasite and its host are useful bio indicators of the impact of environmental quality (30). Nevertheless, the severity of the disease also depends on the pathogenicity of the Monogenoidea species (3) and the nutritional conditions of the host.

In Nile tilapia from the states of São Paulo, Rio de Janeiro and Santa Catarina (Brazil), the emerging parasite Lamproglena sp. (Table 5) has been found since 2000. In the southeast, this crustacean parasite has arisen with the intensification in tilapia culture in cages. However, Lamproglena sp. has not been reported in the Brazilian Amazon, including the state of Amapá. Besides, other parasites have been known to infect this cichlid species in Brazil (Table 5). In Brazil, the diversity of digenean and other crustacean parasitizing Nile tilapia is low (Table 5), but it has also acquired parasites common in native fish, such as o Clinostomum sp., Diplostomum sp., Ergasilus sp., Argulus spinulosus and Dolops carvalhoi.

In conclusion, this study highlights that the diversity of parasites reported for $O$. niloticus grown in Brazil was higher than the one found in the state of Amapá, probably due to differences in size and age of fish, water quality, management and culture system for each fish farm. In Brazil, the parasitic fauna in tilapia is composed by protozoans, monogenoideans, crustaceans and digeneans. However, Trichodinidae are the most frequent protozoan in fish in the south and southeast, while $I$. multifiliis was more abundant in the state of Amapá, in the north. This was the first report of $P$. africana in $O$. niloticus in the eastern Amazon, what broadens its distribution and confirms the presence of this protozoan in Brazil.

\section{Acknowledgements}

We are grateful to CNPq by financial support (grants \# 578159/2008-2 and 556827/2009-0) and for supporting a fellowship to $M$. Tavares-Dias (grant \# 300472/2008-0). 


\section{REFERENCES}

1. Ministério da Pesca e Aquicultura (MPA). Produção pesqueira e aquícola. Estatística 2008 e 2009. Brasília: Ministério da Pesca e Aquicultura; 2010.

2. Banu $\mathrm{ANH}$, Khan $\mathrm{MH}$. Water quality, stocking and parasites of freshwater fish in four selected areas of Bangladesh. Pakistan J Biol Sci 2004; 7:436-440.

3. Martins ML, Azevedo TMP, Ghiraldelli L, Bernardi N. Can the parasitic on Nile tilapia be affected by different production systems? An Acad Brasil Ciên 2010; 82:493-500.

4. Lizama MAP, Takemoto RM, Ranzani-Paiva MJT, Ayroza LMS, Pavanelli GC. Relação parasito-hospedeiro em peixes de piscicultura da região de Assis, estado de São Paulo. Brasil. 1. Oreochromis niloticus (Linnaeus 1957). Acta Sci Biol Sci 2007; 29:223-231.

5. Tavares-Dias M, Martins ML, Moraes FR. Fauna parasitária de peixes oriundos de pesque-pague do município de Franca, São Paulo, Brasil. I. Protozoários. Rev Bras Zool 2001a; 18:67-79.

6. Tavares-Dias M, Moraes FR, Martins ML, Kronka SN. Fauna parasitária de peixes oriundos de pesque-pagues do município de Franca, São Paulo, Brasil. II. Metazoários. Rev Bras Zool 2001b; 18:81-95.

7. Pariselle A, Euzet L. Gill parasites of the genus Cichlidogyrus Paperna, 1960 (Monogenea, Ancyrocephalidae) from Tilapia guineensis (Bleeker, 1862), with descriptions of six new species. Syst Parasitol 1995; 30:187-198.

8. Kazubski SL, El-Tantawy SAM. The ciliate Paratrichodina africana sp. n. (Peritricha, Trichodinidae) from tilapia fish (Cichlidae) from Africa. Acta Protozool 1986; 25:433-438.

9. El-Tantawy SAM, Kazubski SL. The trichodinid ciliates from fish, tilapia nilotic from the Nile Delt (Egypt). Acta Protozool 1986; 25: 439-444.

10. Bush AO, Lafferty KD, Lotz JM, Shostak W. Parasitology meets ecology on its own terms: Margolis et al. Revisited. J Parasitol 1997; 83:575-583.
11. Rohde K, Hayward C, Heap M. Aspects of the ecology of metazoan ectoparasites of marine fishes. Int J Parasitol 1995; 25:945-970.

12. Vargas L, Faria RHS, Ribeiro RP, Marline LS, Moreira HLM, Toninato JC. Ocorrência sazonal de ectoparasitas em tilápias do Nilo (Oreochromis niloticus), em um pesquepague de Umuarama, Paraná. Arq Ciên Vet Zool Unipar 2003a; 6: 61-66.

13. Ghiraldelli $L$, Martins $M L$, Yamashita $M M$, Jerônimo GT. Ectoparasites influence on the hematological parameters of Nile tilapia and carp cultured in the State of Santa Catarina, Brazil. J Fish Aquatic Science 2006a; 1:270-276.

14. Onaka EM. Acompanhamento do estado parasitológico de peixes mantidos em tanques-rede e em ambiente natural nos reservatórios de Nova Avanhandava e Ilha Solteira (SP). Em: Castellani D., editor. I Workshop de Piscicultura do Noroeste Paulista; Votuporanga 13 março de 2009 March 13; Votuporanga, São Paulo; 2009.

15. Vargas L, Povh JA, Moreira HLM, Ribeiro RP, Leonardo JMLO. Efeito de diferentes níveis de vitamina e sobre a ocorrência de ectoparasitos em larvas de tilápias do Nilo (Oreochromis niloticus) no processo de reversão sexual. Arq Ciên Vet Zool Unipar 2002; 5:37-44.

16. Vargas $L$, Povh JA, Ribeiro RP, Moreira HLM, Loures BTRR, Maroneze MS. Efeito do tratamento com cloreto de sódio e formalina na ocorrência de ectoparasitos em alevinos de tilápia do Nilo (Oreochromis niloticus) revertidas sexualmente. Arq Ciên Vet Zool Unipar 2003b; 6: 39-48.

17. Vargas L, Povh JA, Ribeiro RP, Moreira HLM. Ocorrência de ectoparasitos em tilápias do Nilo (Oreochromis niloticus) de origem tailandesa, em Maringá, Paraná. Arq Ciên Vet Zool Unipar 2000; 3: 31-37.

18. Braccini LG, Vargas L, Ribeiro RP, AlexandreFilho L, Takemoto RM, Lizama MAP et al. Ectoparasitos de tilápia do Nilo (Oreochromis niloticus), das linhagens chitralada e GIFT, em diferentes densidades e alimentadas com dois níveis de proteína. Acta Sci Biol Sci 2007; 29: 441-448. 
19. Braccini LG, Vargas L, Ribeiro RP, AlexandreFilho L, Digmayer M. Ectoparasitos de tilápiado-nilo (Oreochromis niloticus) cultivados em tanques-rede nos rios do Corvo e Guairacá, Paraná, Brasil. Rev Bras Parasitol Vet 2008; 17:24-29.

20. Azevedo TMP, Martins ML, Bozzo FR, Moraes FR. Haematological and gills response in parasitized tilapia from valley of Tijucas River, SC. Brazil. Sci agric 2006; 63:115-120.

21. Ghiraldelli L, Martins ML, Jerônimo GT, Yamashita MM, Adamante, WB. Ectoparasites communities from Oreochromis niloticus cultivated in the State of Santa Catarina, Brazil. J Fish Aquatic Sci 2006b; 1:181-190.

22. Martins ML, Ghiraldelli L. Trichodina magna Van As and Basson, (Ciliophora: Peritrichia) from cultured Nile tilapia in the State of Santa Catarina, Brazil. Braz J Biol 2008; 68:169-172.

23. Ghiraldelli L, Martins ML, Adamante WB, Yamashita MM. First record of Trichodina compacta Van As and Basson, 1989 (Protozoa: Ciliophora) from cultured Nile tilapia in the State of Santa Catarina, Brazil. Int J Zool Res 2006c: 2:369-375.

24. Basson L, Van As J. Trichodinidae and other ciliophorans (Phylum Ciliophora In: Woo, P.T.K., editor. Fish diseases and disorders: Protozoan and metazoan infections. UK: Biddles, King's Lyn; 2006.

25. Alves DR, Luque JL, Paraguassu AL. Ectoparasitas da tilápia nilótica Oreochromis niloticus (Osteichthyes: Cichlidae) da estação de piscicultura da UFRJ. Rev Univ Rural Ciências e Vida 2000; 22:81-85.
26. Marengoni NG, Santos RS, Gonçalves-Júnior AC, Gino DM, Zerbinatti DCP, Lima FS. Monogenoidea (Dactylogyridae) em tilápiasdo-nilo cultivadas sob diferentes densidades de estocagem em tanques-rede. Arq Bras Med Vet Zootec 2009; 61:393-400.

27. Silva AS, Monteiro SG, Doyle RL, Pedron FA, Filipetto JE, Radunz-Neto J. Ocorrência de Clinostomum complanatum em diferentes espécies de peixes de uma piscicultura do Município de Santa Maria - RS. Vet Zootec 2008; 15:27-32.

28. Dickerson HW. Ichthyophthirius multifiliis and Cryptocaryon irritans (Phylum Ciliophora), In: Woo, P.T.K., editor. Fish diseases and disorders: Protozoan and metazoan infections. UK: Biddles, King's Lyn; 2006.

29. Gonçalves ELT, Jerônimo GT, Martins ML. On the importance of monogenean helminthes in Brazilian cultured Nile tilapia. Neotrop Helminthol 2009; 3:53-56.

30. Sanchez-Ramirez C, Vidal-Martinez VM, Aguirre-Macedo ML, Rodrigues-Canul RP, Gold-Bouchot G, Sures B. Cichlidogyrus sclerosus (Monogenea: Ancyrocephalinae) and its host, the Nile tilapia (Oreochromis niloticus), as bioindicators of chemical pollution. J Parasitol 2007; 93:1097-1106. 